\title{
Heidegger and the Overcoming of Metaphysics
}

\author{
George 7. Seidel
}

Aвstract Heidegger revisits German idealism after the "turn" in his thought in the mid-1930's. There are a couple of reasons for this. One is philosophical, if not "theological" in his sense of that term. The other is personal. This later reason is emphasized by Otto Pöggeler, who suggests that after 1945 Heidegger sought to understand what had gone wrong in the tragic European debacle. Heidegger will lay the blame at the doorstep of what he terms onto-theology and the subjectivism he sees as endemic to the German idealist tradition, above all as exemplified in Hegel's “onto-theo-ego-logy" The article explores Heidegger's reading of this tradition of German philosophy as it begins with Leibniz and culminates in Nietzsche.

It is the Event itself that makes possible the overcoming of metaphysics and its onto-theology. As Heidegger says in Contributions to Philosophy (From the Event), the ens realissimum (das Seiendste) "is" no more. It is the Event (Ereignis) that is the "most real," since it is the Event that shows up and manifests itself as the revelation of the truth of Beinge in Da-sein, the being that is there in the Event.

KeYwords German idealism; Heidegger, Martin; onto-theology; the Event 
It soon becomes obvious to anyone studying the philosopher that it is not possible to understand Heidegger simply by reading Heidegger. ${ }^{1}$ The philosopher from the Black Forest is in constant dialogue with the tradition that precedes him, above all that of German idealism. He is continuously interpreting and re-interpreting the works of Fichte, Schelling, and Hegel, albeit in his idiosyncratic fashion.

Heidegger revisits the German idealists after the turn in his thought in the mid-30's. There are a couple of reasons for this. One is philosophical, if not "theological" in his sense of that term. The other is personal. This later reason is emphasized by Otto Pöggeler, who suggests that after 1945 Heidegger sought to understand what had gone wrong, and to determine the origin and shape of the tragic European debacle. ${ }^{2}$ Heidegger will lay the blame at the doorstep of onto-theology and the subjectivism he sees as endemic to the German idealist tradition. Though Heidegger had begun to suspect the complicity of German idealism in the disaster earlier than 1945, perhaps ten years earlier, in fact, with the "turn" in his thought. Indeed, in the late 30's and early 40's, in Metaphysics and Nihilism (1938-9), Heidegger realizes that he is going to have to take another look at the German idealists to see if there may not be more there than simply onto-theology. The beginning of this review may be seen already in 1938-9 with Hegel: Negativity (1993). ${ }^{3}$

In a series of seminars dating from 1941-3, essentially on Schelling and German idealism, he emphasizes the importance of Kant's transcendental idealism as the basis for the notion of the Absolute. However, Heidegger insists that the event (Ereignis), which he describes as the central focus of his thought after the mid-1930's, ${ }^{4}$ is not the Absolute or its opposite (finite as opposed to in-finite). Rather, it is "Beinge itself" ("Seyn selbst"), experienced as Beinge and not as a being (ein Seiendes), least of all as a posited Supreme Being; and this in spite of the fact that Beinge appears (west, shows

1. Special thanks to Simeon Goodman for his technical assistance with the texting and reformatting of the article

2. (Pöggeler 1992, 246). One could quibble with Pöggeler here. World War I was certainly a European debacle. World War II had a much more specifically German component to it.

3. Citations from Heidegger's Gesamtausgabe will be followed by the publication date (see bibliography), then the page number.

4. As he says in a footnote added later to the Letter on Humanism, "Since 1936 'Ereignis' has been the key word in my thinking” (Heidegger 1976, 316, n. a).

5. "Beinge" is an older spelling of "being," in the same way that Seyn is an older spelling of Sein. It refers of the "being" of Da-sein, the being that is there in the Event (Ereignis), as becomes clear in the various Unpublished Treatises (Part III of the Gesamtausgabe). 
up, reveals itself) and alone "is," ${ }^{6}$ and gives rise to the letting-be of beings. Such a letting-be of beings cannot occur with the Absolute but only with Beinge (Heidegger 2011, 215).

\section{ONTO-THEOLOGY AND ITs OvERCOMING}

Heidegger's Metaphysics and Nihilism, dating from 1938-9, continues many of the themes that surface already in Contributions to Philosophy, Besinnung, and other Unpublished Treatises from Part III of the Gesamtausgabe. The work, with its special emphasis on the nineteenth century, stands in conjunction with other lecture series and seminars given around the same time. There is The Metaphysics of German Idealism (1991), lectures given in 1941; Hegel: Die Negativität (1993), which date from 1938-9, 1941; and Die metaphysischen Grundstellungen des abendländischen Denkens (2008), seminars in 1937-8, 1941-2); along with a couple of seminars on Nietzsche (Heidegger, 2004, given in 1937 and 1944, along with the earlier two-volume work entitled Nietzsche published in 1961. Granted, Nietzsche would not normally be classed among the German idealists. Nevertheless, as an instance of the metaphysics that needs to be overcome, in Heidegger's view, he represents the culmination of that tradition, indeed of the whole of the Western tradition of philosophy.

\section{ONTO-THEOLOGY}

One of the principal concerns of Metaphysics and Nihilism is the overcoming of metaphysics, above all getting rid of what is termed "onto-theology." The overcoming of metaphysics, Heidegger says, derives from Beinge (Seyn) itself, taking its beginning in the letting-be of beings attuned to the truth of Being, in-standing (or in-stancing) in Da-sein (Heidegger 1999, 8-9) in the event. One cannot get to Beinge from beings, as Heidegger often insists, since it is Beinge that lets (or makes) beings be (Heidegger 1999, 10-1). Beinge-historical thinking will thus throw an entirely different light on metaphysics and, by the same token, upon the human being (Heidegger 1999, 13). The over-coming (Über-windung) of metaphysics is like a gust of wind (Windung der Winde), which is also a revelation of Beinge (Heidegger 1999, 14-5).

6. In their classic dictionary of the German language the Brothers Grimm point out that 16th and 17th century theological (and, earlier, mystical) authors use the word Wesen verbally in relation to God in terms of its connection with life. Wesen, again taken verbally, is tun und treiben (do and produce), begeben (come to pass, issue), auftreten (come forward, step out into the open, show up, reveal itself). 
At the end of the "Onto-theo-logical Constitution of Metaphysics" Heidegger makes the point that the causa sui God (the God that is the cause of itself) must be sacrificed in order to get closer to the true or godly (göttlichen) God (Heidegger 1957a, 71). Once that is done, it may be possible to get out of metaphysics and into that "reality" which is the eventful event (Ereignung) as en-owning (Heidegger 2006, 77-8 and 131). The problem, in Heidegger's view, lies in the fact that Western languages are largely metaphysical and generally characterized by onto-theo-logy (Heidegger 2006, 78).

So what is onto-theology? The term has its origin in the Transcendental Dialectic of Kant's Critique of Pure Reason. It occurs in the context of Kant's criticism of the ontological proof for the existence of God (A 632, B 660). In Kant, onto-theology represents the attempt on the part of Natural Theology to demonstrate the existence of God through concepts alone. More specifically it refers to the ontological proof for the existence of God as it is found, for example, in Descartes (A 602, B 630). Put simply, the ontological proof argues that if one understands the idea of the essence of God, then that essence necessarily implies existence. The two prime examples of onto-theology for Heidegger are Spinoza, with his notion of God (Substance) as causa sui, and Hegel, for whom "the Absolute is and wills to be with us from the start." 7 Though Heidegger finds onto-theology throughout the history of metaphysics, perhaps on the basis of Kant's view that all proofs for God's existence reduce themselves down to the ontological proof. Thus, according to Heidegger there is the same onto-theology in the metaphysics of Plato and Aristotle, in Christian metaphysics, and in the metaphysics of the modern period from Descartes to Nietzsche (1993, 81). A rather broad swath! Put simply, Onto-Theo-Logik looks upon God as merely the ground of the ontic, the reason or cause of being as a whole (Heidegger 1957a, 51).

This specifically Heideggerian program for the deconstruction of the history of metaphysics consists in getting being out of theology and God out of metaphysics. "Faith," as Heidegger says in a 1951 seminar in Zürich, "does not require the thinking of being. And in no way can being be considered the ground or essence of God" $(1986,436)$. Being is to be extricated from theology, he argues in Contributions, because if it is not, then being itself gets missed in favor of beings, the notion of the Supreme Being (das Seiendeste, the most being of beings) adduced as their cause. This is but 
the "God" of metaphysics (Heidegger 1989, 472). For Heidegger, again, the God that is the essence of metaphysics is that of a causa sui, a self-causing being. One cannot worship such a causa sui, nor can one pray to it or fall down on one's knees before it, or make music to it, or dance before it (Heidegger 1957a, 71). ${ }^{8}$

So far as Heidegger is concerned, traditional metaphysical thinking-and Christian theology simply takes this over into itself-attempts to get to a notion of God as simply the absolute and infinite ground of being and the cause of beings (Heidegger 1997, 242). This is but the glorification of the principle of causality, the transfiguration of the crudest of explanations (Heidegger 1997, 240). Such a notion of God as creator is drawn from the world of beings (Heidegger 1997, 236). The approach, in Heidegger's view, will not work, since Beinge really leaves no trace in beings (Heidegger 1997, 202, 353). When Greek metaphysics, with its anthropomorphism, was transported into Christian theology, it became thoroughly impossible for metaphysical speculative thinking to understand the meaning of the last God. The theme of the passing by of the last God is explored in Contributions to Philosophy (Heidegger 1989, 405-17).

Further, in taking everything in terms of Aristotelian causes and principles, metaphysics, and Christianity with it, also became entirely incapable of thinking the special anthropology of Da-sein. Indeed, Heidegger insists that there is no metaphysics of Da-sein (Heidegger 1997, 386). By the same token, this approach made it impossible to understand the Seyn in Da-sein and, hence, Sein as well. Metaphysics ended up with a Supreme Being as the cause of beings. In addition, this meant that metaphysics became incapable of grasping the "ontological difference," the distinction between being (das Sein) and beings (das Seiende or die Seienden). From that point on, it was no longer possible to recognize Seyn, which alone makes it possible to have beings by letting them be. Christian theologians thereby rendered themselves totally

8. One might indeed argue that the notion of causa sui does, indeed, predate Spinoza (or Descartes). For example, among the scholastics there is a distinction made between esse a se and esse $a b$ alio, with its obvious background in Aristotle. And since God would not have his being from another, as caused by another, then he must have that being through himself, and would thereby represent a self-causing being. Also, in the neo-Platonic tradition there is Plotinus' One as "cause of itself" (aition eautou) in the Enneads VI, 8, 14 (toward the end). Though Plotinus insists that any such self-making in the context of the One (alias the Good) is to be understood as occurring simultaneously with itself, the eternal "bringing into existence" as self-disposing (but not all-powerful). Still, to speak of the One as thus "cause of itself" is, according to Plotinus, to speak metaphorically, not literally (Enneads VI, 8, 20). In any case, whether in Plotinus such a "self-disposing" is free or necessitated is difficult to say. It could be either, or both. 
incapable of understanding the first beginning, since they had become overly enamored with the causal thinking of Aristotelian metaphysics.

\section{BeInge ANd German IdEALISM}

Heidegger recognizes the importance of Leibniz for an understanding of the development of German idealism. Thus, to Leibniz' question: "Why is there something rather than nothing?" Heidegger notes that metaphysics answers: Be-cause... (Ur-sache, the original "thing"). In a supplemental note on Leibniz in The Metaphysics of German Idealism regarding the "answer" that Leibniz gives to this "Why" question, namely, "because nothing is simpler and easier than anything," Heidegger insists that nothing is not simpler or easier. Indeed, being must "be" in order that the nothing might be. And so far as the showing up of Beinge would be concerned, this is neither easy nor difficult, but is already more than enough for reflection and thinking (Heidegger 1991, 199).

The perspective of Beinge-historical thinking, on the other hand, would see the letting-be of beings as itself a manifestation of Beinge, Beinge as a divine letting go (Seynsverlassen), as a denial of itself (Verweigerung, [1999, 19]). ${ }^{9}$ Beinge is not to be understood as the reason or cause of beings, says Heidegger, and never as their immediate ground. The Er-eignis, the en-owning event, alone "izzes" (istet, $[1999,21]) .{ }^{10}$ The "God" that is the cause or reason for beings is, again, but the God of metaphysics. For the German idealists, according to Heidegger, metaphysics is but "an empty foyer" for what is really important to them, namely special metaphysics and, more specifically, God (Heidegger 1993, 53). On the other hand, the Beinge that lets be not only lets beings be but also lets its-self be in the en-owning event.

Indeed, as Heidegger says in "Zum Wesen der Sprache" (2010), Beinge "izzes" itself: "Das Seyn ist und istet das Seyn (Heidegger 2010, 17); the Word silently reveals itself (west), standing in the silence of Beinge: that Beinge izzes (istet) Beinge (Heidegger 2010, 20). In saying that (Das Seyn istet) one is saying that Beinge preserves itself in its giving way (überlassen, in its giving itself up) to its showing up (Heidegger 2010, 25). "Everything 'is' because it 'izzes' in Beinge as the event" (Heidegger 2010, 31). Again, this is not a self-causing of itself, as though it were its own effect (as Spinoza would have it). Beinge "izzing" itself in the event is a unique sort of "transitus." In

9. See: Philipians 2:2.

10. Or similarly in Zum Ereignis-Denken, Beinge "is" not a being, but it "izzes" ("istet") beings (Heidegger 2013, 1343). Theodore Kisiel notes that the "istet" employed here is that of Eckhart, which is both active and transitive (Kisiel 2006, 275). 
the coming of the event there comes what has been (Gewesene), and that is the originating denial involved in its coming (Heidegger 2010, 28). There is a naysaying involved in the event-ing. ${ }^{11}$

The notion of possibility (Leibniz) or making possible (Kant's apriori) has no place with respect to Beinge, since the event represents the "ground" for the possibility of thinking relative to that which makes possible (Heidegger 1999, 25-6). Standing in the clearing of Beinge (the event) is the essence of freedom. Indeed, freedom, he insists, is first really freedom in virtue of the fact that Beinge happens amongst beings in the event (Heidegger 1999, 31). True freedom occurs only with the coming into its own of the In-amongst in the event, the coming unto its own as the "en-owning" of Da-sein. In a seminar given in 1939, Vom Wesen der Sprache, Heidegger says, "Freedom is not the 'condition of the possibility' of the word; rather, it is in itself as belonging to the eventful event-the stillness of Beinge itself; it is "Word" (Heidegger 2010, 76). It is Beinge as decision that is at the basis of the distinction between being and beings (the ontological difference), since this free decision (Entscheidung) cuts out the distance (Ent-scheidung) between the divine and the human in the eventful event (Er-eignung, Heidegger 1993, 43). Metaphysics, as the truth of beings-not the truth of being, which is forgotten in favor of beings-is overcome by Beinge, through the grounding of the truth of Beinge as the Beinge of truth (Heidegger 1999, 34). With the transfer of the being-question to Da-sein, there is also the overcoming of every form of subjectivism and "anthropomorphy" (Heidegger 1999, 37). As he says in The Metaphysics of German Idealism, the standing-in of Da-sein is the overcoming of subjectivism. What this means is that the human person can no longer be understood as subject (Heidegger 1991, 51). In his "Letter on Humanism," Heidegger makes the point that thinking, above all speculative thinking, will never overcome metaphysics by transcending it, by trying to climb still higher above it, by climbing over it, or by somehow getting beyond it. Rather, it would be overcome by climbing back down again into the nearness of what is most near (Heidegger 1976, 182). Transcendence will not get one to where one needs to go; rather, de-scendence, in imitation of Beinge's going below, will alone do the trick. ${ }^{12}$

11. Sagen der Neinung in der Er-eignung (Heidegger 2010, 24). Again, the setting It-self aside of Philippians 2:2. According to Krzysztof Ziarek, the use of the word "istet" denotes a mode of being that would be unique (einzig), occurring only one time (einmalig) in eventuating itself. Das Seyn istet das Seyn changes an intransitive verb into a transitive one (Ziarek 2013, 150-1).

12. In a gloss Heidegger attaches to the passage in the second introduction to Being and Time describing Dasein as transcendence pure and simple, he notes that transcendence belongs to the truth of Beinge: the event (Heidegger 1977, 51). 
In view of Heidegger's animadversions toward technology, it may seem odd that he would speak of modern technology as the "truth" of Beinge, as he does in "Metaphysics and Nihilism" (Heidegger 1999, 37). However, this occurs in virtue of the fact that the "truth" that the techne of technology represents, as the model for the creator God, is revealed as untrue. Again, the techne of technology represents the Ge-stell, the set-up, which, used as the model for the creator God-which is untrue-is then transferred back to the human being ("made in the image and likeness of God"). Heidegger made this point earlier in the philosophy of science section of Contributions (Heidegger 1989, 126-66). He repeats it here in an abbreviated form.

Concerning his position regarding subjectivism and the transfer of the being-question from Dasein to Da-sein, Heidegger later adds that one day people will see that the point of Being and Time is not to make the human being central to the philosophical project, but, rather, that of setting the human being aside, as also its primacy in philosophy, above all in subjectivity, so that Beinge can be made to show up and with it Da-sein (Heidegger 1999, 90). Thus, with respect to the proposed third section of part I of Being and Time, namely "Time and Being," he says that it is necessary to think an entirely different sort of Da-sein and its designated temporality, an ecstatic "time," the time-scape of the In-between, or better, the In-amongst (Heidegger 1999, 131). Or, as he also notes, Being and Time is not just some more basic metaphysics. Still, contained within it is an entirely different beginning concerning the revelation of Beinge, and thus a more origin-al relation to the first beginning. The "destructuring" of metaphysics, announced in Being and Time, is really a return to the origin (Heidegger 1999, 125), a freeing-up ("Freilegung")of the beginning, as he says in Besinnung (Heidegger 1997, 66).

However, going back to the first beginning is not simply a matter of going backwards (zurück), but of looking ahead to the pressing question of what is unquestioned, namely the truth of Beinge (Heidegger 1999, 39). Beinge's history is first able to be experienced out of the ascertaining (Erfragen) of the truth of Beinge, which asking is itself owned up to (er-eignet) by Beinge (Heidegger 1999, 52). The overcoming of metaphysics has to do with the manner of being there (da-seinshaft, Heidegger 1999, 39), with a very different sort of being-there.

\section{NiETZSCHE AND NiHILISM}

On the other hand, Nietzsche's letting-be of beings as the chaos of the unconditioned will-to-power is the ultimate nihilism (Heidegger 1999, 38). Metaphysics is the check on the truth of Beinge, which through the 
super-man (Nietzsche's Übermensch) reaches its highest world-friendly power and in the God-man (Christus) its most world-unfriendly impotence, the battle between the two playing itself out over the centuries. While, hidden within this conflict, is the overcoming of metaphysics that belongs to Beinge (Heidegger 1999, 46). Metaphysics is the check on the truth of Beinge for Nietzsche in that he is not really interested in the truth. For him beauty (art) is of greater value than truth (Heidegger 1999, 50).

As Heidegger says in his Nietzsche lectures in the mid-thirties, Nietzsche represents the devaluation of all value (that is, moral) interpretations of metaphysics in favor of the "value" of the will-to-power, domination over the earth. Heidegger does not like value philosophy, whether in its Platonically based or in its upended-Nietzschean form. No one, he says, is going to "live" or "die" for values (Heidegger 2015, 10). The Nietzschean super-man, according to Heidegger, is absolute subjectivity (N I:44-45). His "psychology" represents the complete unfolding of Descartes' Meditations on First Philosophy (N I: 52). Nietzsche's "Gott ist tot" is not atheism, but rather a formula for the basic experience of an event in Western history (Heidegger 1961, 183).

In Metaphysics and Nihilism, on the other hand, Heidegger insists that there is a positive as well as a negative side to Nietzsche's "God is dead" (Heidegger 1999, 179). Plato's supersensible world of ideas is dead. So also is Descartes' world of subjective certainty (Heidegger 1999, 181-2). But the super-man as will-to-power lives! (Heidegger 1999, 183-1). Nietzsche's Gott ist tot is "positive," from Heidegger's point of view, in that it represents the overcoming of one species of onto-theology, namely Plato's "divine" world, the world of the supersensible ideas.

Nietzsche's nihilism is precisely that, namely nihilism, because it ignores being in favor of beings as a whole (Heidegger 1999, 205). The absurdity of all this does not touch being, however; much less does it touch that which so far as beings are concerned is nothing (Heidegger 1999, 207). The "nothing" referred to here could be either being or Beinge, since from the point of view of beings both are equally nothing, no-thing. Nietzsche, Heidegger notes, is in the voluntarist tradition, which stretches back through the German idealists and Leibniz to Descartes. And, perhaps, back even further than that into the late Scholastic theology of Scotus, Ockham, and Gabriel Biel as well, as he remarks elsewhere (Heidegger 2005, 369). Of course, Nietzsche is very much into will, not just the will-to-power, but Will as such (Wille), pure will (Heidegger 1999, 210). Being is, for Nietzsche, identical with life (Heidegger 2008, 297); and where there is life there is, for Nietzsche, the will-to-power. Further, in Nietzsche's inverted Platonism, the intellect is 
but a condition of this will-to-power (Heidegger 2008, 305). Schopenhauer strongly influenced Nietzsche, who, says Heidegger, thinks metaphysically in the crudest Schopenhaurian fashion (Heidegger 2015, 502).

That ontology is really theology (onto-theology), in Heidegger's view, goes back beyond Leibniz' "why" question ("Why is there something rather than nothing?") to Plato and Aristotle. ${ }^{13}$ This is the case with Nietzsche as well. According to Heidegger, Nietzsche's "Eternal return of the same thing" (ewige Wiederkehr des Gleichen) is really theology! (Heidegger 1999, 215). Indeed, in his earlier lectures on Nietzsche, Heidegger notes that Nietzsche himself speaks of the return of the same (Wiederkunft des Gleichen) in terms of faith or belief (Glauben), that is, something that is held to be true (Für-wahr-halten). Heidegger grants that this belief in an eternal return is not religion as such, except in the sense of a "this world" religion ("Diesseits," Heidegger 1961, 382-6). As he says in a seminar on Nietzsche in 1937, the eternal return is being set free from the Heraclitean flux; it is the Will's being freed from getting into a rut (Heidegger 2004, 28).

In the end, however, Heidegger will become quite negative regarding Nietzsche and his "theology." From the point of view of Da-sein and the event Nietzsche's basic metaphysical position must be understood as farthest removed from Da-sein, as the most profound forgetting of being, and as the broadest flight from the truth. Disowning (Enteignung-compare event, (Heidegger 2004, 166). Disowning Da-sein as the locus of all places (Heidegger 2004, 183). ${ }^{14}$

Being is no more able to be represented objectively for metaphysics than is Beinge. After all, metaphysics is interested primarily in beings. And Beinge is, and is out of hiding (entborgen), insofar as it occurs through transformation of the human being into Da-sein (Heidegger 1999, 54). Freedom shows up out of Beinge. Beinge owns up to the showing-up. "Out of freedom" is the indication that a short cut (Richte) is taken (Heidegger 1999, 62). Being away and staying away from the ground (Ab-grund), represents the essential denial (Verweigerung) of being after the fashion of a ground (Grundhaften)-the ground (Ungrund), groundless (Grundlose, Heidegger

13. Heidegger makes an intriguing point with respect to Leibniz. He credits Leibniz with the idea behind the life insurance industry and its actuarial tables, as based upon his notions of universal characteristics and the pre-established harmony (Heidegger 1999, 167).

14. It would, of course, be helpful if Heidegger would complete his sentences or write in complete sentences. What he seems to be saying here is that Nietzsche's thought, given his metaphysics, had little or no understanding of the event and Da-sein, which involved a disowning, a setting aside of divine prerogatives. Nietzsche in Heidegger's view simply sets it all aside, disowning the whole business. 
1999, 64). As Heidegger says in Contributions, the In-amongst of Beinge is away-from-the-ground. It is ground-less in the sense that no reason (Grund) can be given for Beinge's showing up (Heidegger 1989, 509). And why must the In-amongst be away from the ground? So that $\mathrm{Da}$-sein would be finite, he says (Heidegger 2008, 35). In the same vein, Heidegger later notes that in the other beginning Beinge is, indeed, the most real (Seiendste), but, at the same time, utterly finite (Endlichste) - the farthest away from the ground (Abgründigste)-Ereignis (Heidegger 2008, 48). Its being away and staying away from the ground implies a dis-owning (Verweigerung) of its true identity. "Da-sein ex-sists for its own sake insofar as it is the grounding of the truth of Beinge, that is, it comes into its own (er-eignet)." Which means that it is necessary to begin the questioning elsewhere. From whence? From the truth of Beinge (dis-owning-showing-up-mystery. The human being as Da-sein.) (Heidegger 1999, 66).

The Word, taken simply, bespeaks the distinction between beings and being (the ontological difference), its arrival left in the dark, above all when the really real (Seiendheit) of beings takes over as cause (Heidegger 1999, 73), as Supreme Being or the First Cause of beings (Heidegger 1999, 76). The ontological difference between being and beings represents an occurrence in Beinge's history (Da-sein). Indeed, metaphysics is grounded in this ungrounded issuing forth (Austrag) without knowing it: the projection of being-the projector-proceeding out of the standing-in (Da-sein). (Heidegger 1999, 81). In the first beginning, there is the revelation of the Beinge, which does not appear. In the other beginning, the decision itself is, as the revelation of Beinge, to be away from the ground (Ab-grund) as the In-amongst (Heidegger 1999, 78).

The beginning of metaphysics is not Heraclitus or Parmenides, this is natural philosophy (in the Aristotelian sense), which is neither philosophy nor nature. Rather, metaphysics begins with Socrates because of his concerns about the human being and striving toward the good (Heidegger 1999, 89); which is the highest (ethical) idea. Kant is also in this tradition, in Heidegger's view, in that Kant seeks a place for "belief" (Heidegger 1999, 92); which is really ethics. ${ }^{15}$ As Heidegger says, the beginning of metaphysics, then, is the first ending of the first beginning, the ending that is the preparation for the beginning of the end, which lasts well beyond the other beginning (Heidegger 1999, 96). Well, after all, it begins with Plato, and lasts all the way to Nietzsche. Christian thinkers approve of Plato but would prefer to jettison Nietzsche. However, according to Heidegger, they

15. See. the preface to the second edition of the Critique of Pure Reason, $\mathrm{KrV}, \mathrm{B} \mathrm{xxx}$. 
are both the same (Heidegger 1999, 157), the latter simply an inversion of the former. Metaphysics is overcome once it is revealed in the In-standing of the In-amongst (Da-sein), that it is through that Beinge that all things came to be. This means that the viewpoint of metaphysics, namely the notion of God as supreme cause of the world, becomes simply otiose. Metaphysics is simply overcome in and with the realization [in both senses of that term: recognized and made real] of the Er-eignung-in both senses of that term: as both what opens up one's eyes to (er-äugen) as also what en-owns (er-eignen).

Metaphysics is the truth of beings. As such, it represents the denial of the truth of Beinge, which denial is Beinge itself. The overcoming of metaphysics represents the taking back of that denial, the overcoming of the pre-sounding (Vorklang) of the other beginning (Heidegger 1999, 99). ${ }^{16}$ Beinge denies itself in the first beginning. Thus does the time of the In-amongst (the timeslot of the moment), and being itself, become hidden (Heidegger 1999, 127). The overcoming of metaphysics also comes from Beinge, taking back the denial. Heidegger notes that in Platonism there is a relation between the soul and what is truly real, namely the ideas. It is quite otherwise with the other beginning. Beinge and its manifestation is neither soul nor beings (Heidegger 1999, 119). Similarly, he notes that already in Plato there is a connection made between mathematics and "theology." Numbers, geometrical figures, mathematical "objects" generally, are ideas for Plato, which are for him what is real. This comes to fruition in Descartes, according to Heidegger, when truth becomes certitude, like the certainties of mathematics (Heidegger 1999, 155-6). In Leibniz they are among the eternal verities.

Speaking with respect to care (Sorge) and attunement (Stimmung, or mood)-both of which figure prominently in Being and Time-Heidegger says that care has everything to do with the truth of Beinge. Similarly, he speaks of attunement as having been tuned by the intoned voice of silence as the origin of the Word. If thinking about being is taken up as what is said in the Word in the light of the lit-up Beinge, the other beginning is doing a repeat performance (wieder-holt) of the first unrepeatable beginning (Heidegger 1999, 134-5). The origination of beings cannot, of course, be

16. "Die Überwindung der Vorklang des anderen Anfangs" (Heidegger 1999, 99). The word Vorklang does not exist in German. Klang is the clang of a bell; a Vorklang could be the barely audible cling before the awaited clang. In Contributions, Heidegger speaks of the Vorklang of the revelation of Beinge in the letting-be of being (Heidegger 1989, 117). In other words, there is a hint, cling, as to what is involved in first beginning before it is rung in with the clang of the other beginning. 
repeated. However, the meaning of that story can be given a new and different reading in the light of the other beginning.

The history of Beinge is not to be thought of rationally or deduced in a step-by-step development in the manner of a Hegel (Heidegger 1999, 165, see Hegel's Phenomenology of Spirit). In Heidegger's view Hegel exalts the historical to the level of the absolute, and thereby reduces the truly historical (Geschichte) to nothing (zernichtet). It is this, he maintains, that gives rise to the problem of "historicism" in the nineteenth century (Heidegger 2009b, 102-3). ${ }^{17}$ The metaphysics of Hegel, according to Heidegger, is a mix of Christianity and conceptual knowledge (Wissenschaft), the identification of that knowledge with world spirit, which has nothing to do with the belonging of Da-sein to Beinge as the event. All this is inexplicable to, and hidden from, the sort of metaphysical or speculative thinking that Hegel indulges in. The explanation of beings in this fashion is, in Heidegger's view, fundamentally inimical to the poetical character or revealing (Wesen) of Beinge (Heidegger 1999, 171-2).

According to Heidegger, Hegel is the last great metaphysician of Western metaphysics (GA 29/30:420). In his lectures on the Phenomenology of Spirit, Heidegger says that for Hegel the Absolute is Spirit (Geist); Spirit is knowing (logos); Spirit is the "I" (ego); Spirit is God (theos); Spirit is actuality (on). This means that the being-question in Hegel is basically onto-theo-ego-logical. It is onto-theology, along with a heavy dose of subjectivity (ego).

Metaphysics is authentic, true to itself when it thinks beings instead of being. Thus, Beinge remains unthought in metaphysics. And to the extent that Beinge is unthought, the truth (Unverborgenheit, unhiddenness) of beings remains unthought as well. Beinge is, after all, that truth (Heidegger 1999, 216-8). Beinge's failing to appear (Ausbleiben) is Beinge itself as this failing to appear, which failing to appear is true of being as well. Is this being $(\text { Sein })^{18}$ denying itself in favor of beings? Being is, like Beinge, no-thing so far as beings are concerned (Heidegger 1999, 219-21). The "It" $(E s)$, as being (sein) with the locale of its arrival, as the taking up quarters in its being away (Unterkunft seines Ausbleibens), it is the "where" of the "there," and "is" being itself and is thus termed Da-sein (there-being) and concerns itself (angeht) with human beings (Heidegger 1999, 223). Being,

17. For Heidegger the most extreme form of historicism is an absolutized relativism (Heidegger 2009b, 114); and it is to be laid at the doorstep of Hegel.

18. Or does Heidegger, perhaps, mean Beinge (Seyn) here? It could be either, as, from the point of view of beings, both being and Beinge are "nothing," as he indicates later in the same passage. 
Heidegger goes on to say, is a puzzle that gives itself to be thought, but not by reason. What gives it to be thought is the Es (Heidegger 1999, 235). Heidegger is here anticipating the meaning of the "It" (Es) in the Es gibt Sein, Es gibt Zeit of being and time in his 1962 lecture entitled "Time and Being" (Heidegger 1969, 20-1).

The truth of being's failure to appear also makes everything salvific in beings to disappear, the openness of the Holy as well, which eclipses every divine light. The eclipse hides the divine being that is simply out of place (Fehl Gottes); which leaves humans homeless and at a loss (Heidegger 1999, 253). Fehl Gottes could also be rendered: God gone missing. There is a mystery involved in the history of being (Heidegger 1999, 255). The failure of metaphysics to ask about the ontological difference between being and beings means that it fails to ask about being as well (Heidegger 1999, 265). This forgetting of being implies not having a clue (Nichtahnen) regarding the truth of Beinge (Heidegger 1999, 42). Or, as he remarks in "The Being-Historical Determination of Nihilism" (1944-6): the reserved character (Verschlossenheit) of the Holy darkens every lighting of the divine. This darkening establishes and conceals the God gone missing (Fehl Gottes, $\mathrm{N}$ II:394). And in the text this is later tied up with the divinity's denial of its-self (sich verweigert, N II: 396).

The point Heidegger is making here is that if the distinction between being and Beinge is not made, then the ontological difference between being and beings, which finds its basis in Beinge, does not get made either. This means, among other things, that being gets forgotten. And there is no way for metaphysics, which is essentially conceptual thinking, to catch the beginning reality (anfängliche Wesen) of Beinge, and with it projected being; which is something hidden from metaphysical thinking (Heidegger 1999, 171-2). Metaphysics, according to Heidegger, is in a double bind. It should think being, but is unable to do so, since it cannot get beyond beings. And when it does, all it comes up with is a Supreme Being; which is still just another being, even if it is an-Other being. Metaphysics can get to the ontological difference between being and beings, and thus Beinge, only if it thinks through to Beinge. And this it is incapable of doing. Beinge-historical thinking is non-conceptual. Thus, the essence of Beinge, as also being, is fundamentally inexplicable. For Kierkegaard the Paradox cannot be thought. For Heidegger metaphysical thinking cannot even get that far. It is unable to think through to Beinge; which means that it is incapable of thinking being either. Hence: "Nihilism." 


\section{The History of Beinge}

In The History of Beinge (1998), which dates from roughly the same period as Metaphysics and Nihilism (1999), in other words between 1938 and 1940, Heidegger reiterates some of the same themes met with earlier in that work as also in Contributions and Besinnung (1997).

Though there are some new items as well. Through the event, says Heidegger, there is a negation of Machenschaft (the powers that be) and of the subjectivism that lies behind it. The lord (Herr) is one who lords it over power; which lordship (Herrschaft) resides in Beinge itself (Heidegger 1998, 21). Beinge is not the cause but is rather the action or the actualizing ("Wirkung"), in the sense of bringing forth and letting go forth. The relation between Beinge and beings is a once and for all affair (einzig-einmalig). And the being of the there (Da-sein) represents the sudden moment (Jahe des Augenblicks) of another beginning in the history of Beinge (Heidegger 1998, 23): Beinge in relation to the first beginning (Physis); in relation to the other beginning (Ereignis). Nevertheless, the history "of" Beinge is Beinge's history. Thus does it represent the showing up, the revealing of the truth of Beinge (Heidegger 1998, 27-8).

The history of Beinge spells the end of animal rationale and subjectivity (Heidegger 1998, 30). There is, again, an essential change in the meaning of the human being in and with Da-sein (Heidegger 1998, 89-90). Truly to be human (Mensch-sein) is to be related to Beinge (Heidegger 1998, 99).

The History of Beinge, as with the other unpublished treatises, includes remarks about the then-current events taking place in Europe. Animal rationale, Heidegger says, is the basis for socialism, total wars, technology (Heidegger 1998, 44). Later in the work there are still more reflections on war and peace, total war, and despotism (especially communism, Heidegger 1998, 179). Though English "Bolshevism" is no better (Heidegger 1998, 208-9). There is also an updating of a remark by Carl von Clausewitz in his classic work On War. Heidegger says that total war is not just politics by other means, since "total" wars are never really total. There are always holes in the totality (Heidegger 1998, 50). As may be seen, when Heidegger talks politics he paints with a broad brush.

The Word "of" Beinge-again, it is Beinge's Word-bespeaks beings, divinity encountering humanity; hence the conflict between death (Erde) and love (Welt). (Heidegger 1998, 30-1). ${ }^{19}$ Beinge is not, then, the other

19. It must be granted that love and death as the renderings for Welt and Erde is more than odd in German. Nevertheless, Heidegger's insistence that Da-sein bestrides the conflict between the two, occurs not only in Contributions but also in the other works in this series. 
of beings but is itself this other and is it alone (Heidegger 1998, 53). This is clearly not the "highest"; it is not itself God (Heidegger 1998, 61), most certainly not in the sense of the "God" of metaphysics. Beinge is not to be found in immanence, nor does it dawn on one (erahnen) in transcendence. ${ }^{20}$ It is neither above us, nor in us, nor around us. Rather, we are "in" it, in virtue of the event as the standing-in of the being that stands there-in in $D a$-sein); the happenstance (event) of the betwixt and between is the origin of time-space (Heidegger 1998, 55). Da-sein, says Heidegger, is the tosser in the toss of the eventful event (Er-eignung)-the decision "to be or not to be" (Heidegger 1998, 57). But, as he indicates elsewhere, if Sein is the thrown, and the thrower is Da-sein, then that means that Da-sein, that the being of the $D a$, is a thrown thrower (Heidegger 1993, 15). As he says earlier in Contributions, a special sort of throwness is involved, in that the thrower (Da-sein) is also the one thrown (Heidegger 1989, 303-4; 356). It may be noted that Heidegger uses different words to describe the thrownness (Geworfenheit) of Dasein in Being and Time and the thrownness (Verworfenheit) of the thrown thrower that is Da-sein as it is discussed in these later works.

As Heidegger so often insists, beings show no trace of God (Heidegger 1998, 59). Again, rational theology is not really an option. Though Heidegger grants that in the gifting, as the essential change of Beinge, there is a trace of its truth. Still, Beinge is not the Highest; it is not itself God in the sense of the Supreme Being of rational theology (Heidegger 1998, 61). Nor is it the Absolute (Heidegger 1998, 96) in the sense that word has in the German idealist tradition.

In The History of Beinge, there is an extensive reflection on power and the meaning of power (Heidegger 1998, 62-84). Power, Heidegger says, is a manifestation of Beinge. In the age of metaphysics it is experienced but

For example, in Das Ereignis he speaks of the truth come out of hiding as history, since the light (Lichtung) of Beinge fills "world"-history, thus first bringing about the separation of love (Welt) and death (Erde, Heidegger 2009a, 19). See: Wolfgang Ullrich, who traces the meaning of "earth" in Heidegger (1996, 244). It is, literally, ground (Grund); it is also Gaia, Hesiod's Chaos, Mother (Earth); and, poetically, it is death (Tod), going below (Untergang [269]). As Heidegger says in the Der Ursprung des Kunstwerkes, "Die Erde ist das, wohin das Aufgehen alles Aufgehende und zwar als ein solches zurückbirgt. Im Aufgehenden west die Erde als das Bergende" (Heidegger 1994, 28).

20. The notion of the truth slowly but surely dawning upon one (erahnen) was much in discussion among theologians in the early part of the twentieth century (See potentia oboedientialis). Thus, in The History of Beinge Heidegger speaks of Mensch-sein as a relation to Beinge (Bezug zum Seyn, Heidegger 1998, 99). The basis for this dawning upon one lies in the ability to hear and heed the Logos, p. 180. 
not actually known or understood (Heidegger 1998, 64). Further, power depends upon Beinge, and would not exist without it (Heidegger 1998, 66) ${ }^{21}$ As he says in the Black Notebooks, the Word of Beinge lords it over every power powerlessly (GA 96:60). So far as flaunting (Schein) one's power Heidegger would say that if you've really got it, like the lordship of gracious (Charis) Beinge, you don't need to flaunt it (Heidegger 1998, 68-9). In this connection, Heidegger also considers race and power. Race, Heidegger says, can be used as a means to assert superiority. The basis is not biology or the biological but a metaphysically construed subjectivity (Heidegger 1998, 70-1). The idea of a master race is tied up in, enclosed within, a circle of subjectivity. It is accompanied by violence and brutality (Gewalttätigkeit, Heidegger 1998, 76). ${ }^{22}$

But while there is a lack of the immediate traces of Beinge in beings, there is, nonetheless, a trace of the original historical leaping forth... the manifestation of the truth of Beinge. Beinge-historical thinking follows the traces of Beinge without being able to picture or explain them (Heidegger 1998, 86-88). There are no frills. Bare and bold is its [Beinge's] Word (Heidegger 1998, 87).

With the grounding of the truth as Da-sein, as the being that is there in the event, there occurs a fundamental transformation of the human being as animal rationale (Heidegger 1998, 89-90). Humanity becomes genuinely historical only with the history of Beinge. The eventful event (Er-eignung), the en-owning that is also a coming on its own and coming unto its own, is essentially a coming (Heidegger 1998, 60). The advent springs from the event as the showing up of Beinge. The grounding of this truth as Da-sein, whose being stands-in only through the expectation of humanity; only thus is humankind historical (Heidegger 1998, 93). What ultimately comes in this coming (Kommendste des Kommenden) is the coming of the last God. History, true history, is the showing up of Beinge. The manifestation as what is from the depths, away from the ground, is again and only Beinge itself (Heidegger 1998, 98). The truth of Beinge occurs uniquely in the event. $D a$-sein, as en-owning the light, is cast off (loswerfen) into the openness of the clearing (Heidegger 1998, 101). There is an impoverishment (Verarmung) involved here, a going over into poverty, on the basis of the dis-owning

21. Is this "Du hättest keinerlei Gewalt über mich, wenn sie dir nicht von oben gegeben wäre"? John 19:10.

22. Fred Dallmayr discusses the issue of power, the rulers and the wielders of power (Machthaber) in the context of the Germany of the period. Dallmayr 2001, 247-67. 
(Verweigerung, Heidegger 1998, 107). ${ }^{23}$ And what is this casting off into the openness of the clearing? "Ask Beinge," says Heidegger; and God answers silently, in terms of the beginning of the Word (Heidegger 1998, 105).

The "how" of the event is as a being in which Beinge truly is. The "when" and the "where" is in the clearing of the time-scape (the moment). This means that the coming-of-what-comes plays itself out in time-space. It also means that Beinge is thus not supra-temporal or supra-spatial but is, rather, the In-amongst as away from the ground, ultimate time and ultimate space (Heidegger 1998, 108).

The adoption or incorporation (Er-eignung) of the human being into $D a-s e i n$ and thus in relation to Beinge is not a relation that can be represented or experienced, since it is not a relation made by human beings but by Beinge itself in its history. As Heidegger says, the essential mediation (Wesensmitte) is no-where; it cannot be placed somewhere in space; it is not something at hand, but is, rather, something that first takes place in the appropriation of the human, of humanity, into Da-sein. The human being cannot make this happen but can only prepare for this ultimate coming of what is most near that comes from the afar (aus der Ferne des Nächsten). To the extent that human beings remain outside this preparation they end up in a cul-de-sac unable to find their way back, back not just to the point they got to (Bisherige), but back to the beginning whose pre-dominance Western man all too often has drawn away from (Heidegger 1998, 115).

Da-sein is "more" than human and "less" than God (Heidegger 1998, 118). The last God "is" no God and can be no God. More originally, each and every God is Beinge, given the first beginning as physis; for Parmenides and Heraclitus physis is logos (Heidegger 1998, 132). Heidegger is not saying here what Gnosticism might say, namely that the Da-sein is some sort of intermediate being between the divine and the human. Rather, it is In-amongst. As Heidegger said in Contributions, Beinge manifests itself in time-space as the Between, as what is Amongst, which In-amongst is not grounded in God or in the human, as something that is alive and at hand, but in Da-sein (Heidegger 1989, 263). Thus, when Heidegger says that the last God "is" no God he means that it is not a God in the sense of metaphysics. When he says that more originally (for example, in Parmenides and Heraclitus) "each and every God is Beinge," he is referring to a pre-metaphysical understanding of God in terms of logos, which in his view is named by the ancients, even if not fully understood by them for what it is. 
The way Da-sein stands-in is as care. This caring is the truth of Beinge. And there is conflict involved in the encounter. The conflict between love (Welt) and death (Erde) criss-crosses right through the meeting of the divine with the human right from the start of the eventful event (Heidegger 1998, 123-5). Renunciation ("Verzicht") is not denial (Absage) but an enduring honoring of what is owned up to in the empty space (Aussprung) of the In-between $(1998,125)$, a death freely accepted (Heidegger 1998, 126). As Heidegger will say later, Da-sein takes on error (Übereignung) in its $D a$ and brings it [error] to a conclusion through love $(1998,150){ }^{24}$

Da-sein is the new-found essence of the human being from out of its relation to the truth of Beinge, occurring in Da-sein and grounded therein (Heidegger 1998, 134). The Word is what reveals Beinge, the truth that is Beinge's truth (1998, 140). Da-sein as the truth of Beinge has been and, at the same time, will be (Heidegger 1998, 142), though asking how long being will be misses Beinge's point $(1998,145){ }^{25}$

The other beginning is more of a beginning than the first beginning (Heidegger 1998, 143). Asking after the meaning of being, whose preface or fore-word (Vorwort) is time, is thinking through to the relation to Beinge itself, which is more of a beginning (anfänglicher) than the first beginning, and thus more fundamental than any metaphysics (Heidegger 1998, 145), since metaphysics always thinks relative to the first beginning (Physis).

\section{CONCLUSION}

One of the Contributions that the Event makes to philosophy-the title of that first work in the series of the unpublished treatises, Beiträge zur Philosophie (Vom Ereignis)-is the overcoming of the metaphysics associated with what is termed onto-theology.

Metaphysics and its onto-theology must be overcome, since it represents no more than the truth of beings, not that of being. Being has gotten lost in the shuffle with the showing up of beings. In the end, onto-theology is overcome by Beinge itself, in and through the grounding or earthing of Beinge in Da-sein, which is the truth of Beinge. Metaphysics is overcome, in Heidegger's view, when it is realized (again, "recognized" and "made real") that it is not through some First Cause or Supreme Being that beings come to be but in and through the In-standing In-amongst Beinge of Da-sein that there is a world in which beings are made (or allowed, lassen) to appear. 
The overcoming of metaphysics does not come about through some sort of transcendence. It is impossible to climb above or beyond beings. Indeed, that is precisely the problem with metaphysics. There is too much transcendence, and it is a transcendence of the wrong sort, namely the transcendental subjectivity especially characteristic of German idealism. Instead of a transcending, a climbing-up-beyond beings, there needs to be a descending, a plunging-down-into Da-sein, in imitation of Da-sein's own plunge down into the In-amongst of beings. ${ }^{26}$

It is the event that is the basis for the overcoming of metaphysics and its attendant onto-theology, and this by providing the more basic ontological distinction between Beinge (Seyn) and being (Sein). In Contributions, Heidegger describes this distinction as a new and different sort of "ontological difference," while at the same time insisting that this "new" ontological difference between Beinge and being is the basis for, and is implied in, the earlier ontological difference drawn between being and beings. Thus, it is the distinction between Beinge and being that makes it possible to think the ontological difference between beings and being, thus opening up the possibility for the retrieval of the meaning of being. It may be noted that in the Black Notebooks from the 1940's Heidegger insists that he had this more basic "ontological difference" between Beinge and being already in August of 1939 in the Postscript to "Was ist Metaphysik?" (Heidegger 2015, 167).

So what is onto-theology? Onto-Theo-Logik, says Heidegger, looks upon God as merely the ground of the ontic, the reason or cause of being as a whole. As he puts it, when being becomes the object of metaphysics, as what is above and beyond beings, then that "being" becomes cause, and the way is thereby open for onto-theology and the notion of God as the cause or reason for ontic reality. Again, onto-theology inevitably involves the forgetting of being, since the move from beings to Supreme Being leaves being out of the picture. It is the event that indicates both why onto-theology involves such a forgetting of being, and why it is fundamentally wrong. Since "God," as the ens realissimum, is intimately involved in the whole onto-theological procedure-Hegel's philosophy as the prime example-the specifically Heideggerian program against onto-theology consists in getting God out of metaphysics and being or, at least the wrong sort of philosophy

26. In writing "l'Ereignis désigne l'appropriation du Da-sein par l'Être et la fondation de la verité de l'Être dans le Da-sein," Jean-Marie Vaysse seems to imply that Heidegger takes an adoptionist position, sometimes associated with liberal Protestant theology, that Jesus was "adopted" by the Father as his Son at his baptism in the Jordan (2006, 171-88). It could be that Heidegger does take this position, and I just missed it. He was, after all, good friends with Rudolf Bultmann. 
of being, out of theology. However, the sacrifice of the onto-theological God of the causa sui represents no great loss to religion. One could hardly pray or offer sacrifice to it in any case.

There is yet another reason for overcoming onto-theology. For Heidegger the reason for the debacle that was World War II is to be laid at the doorstep of onto-theology and the subjectivism characteristic of German idealism, as exemplified above all in Hegel's onto-theo-ego-logy. Whether this represents an adequate diagnosis of the historical reality of National Socialism it is difficult to say. At any rate, it represents Heidegger's explanation, and one of the reasons he devotes so much time to the study of the German idealists after the "turn." Nevertheless, while this may account for the rise of fascism in Germany, one may doubt that it will account for the fascisms that arose in Italy or Spain.

It is, then, the event itself that makes possible the overcoming of metaphysics and its onto-theology. As Heidegger says in Contributions, the ens realissimum (das Seiendste) "is" no more. It is the event (Ereignis) that is the "most real," since it is the event that shows up and manifests itself as the revelation of the truth of Beinge in Da-sein (Heidegger 1989, 344).

\section{BIBLIOGRAPHY}

Dallmayr, Fred, "Heidegger on Macht and Machenschaft," Continental Philosophy Review, 34 (2001) 247-67.

Hegel, G.W.F. 1980. Gesammelte Werke, Edited by Herausgegeben von Wolfgang Bonsiepen. Hamburg: Meiner.

Heidegger, Martin. 1957a. Identität und Differenz, Vol. 1. Pfullingen: Neske.

—. 1957b. "Hegel's Begriff der Erfahrung," Holzwege, 3rd ed. Frankfurt am Main: Klostermann, 188.

- 1969. Zur Sache des Denkens. Tübingen: Niemeyer.

- 1976. Wegmarken. Vol. GA 9. Edited by Friedrich-Wilhelm von Herrmann. Frankfurt am Main: Klostermann.

- 1977. Sein und Zeit. Vol. GA 2. Edited by Friedrich-Wilhelm von Herrmann. Frankfurt am Main: Klostermann.

- 1986. Seminare. Vol. GA 15. Edited by Curd Ochwadt. Frankfurt am Main: Klostermann.

- 1989. Beiträge zur Philosophie (Vom Ereignis). Vol. GA 65. Edited by Friedrich-Wilhelm von Herrmann. Frankfurt am Main: Klostermann.

—. 1991. Die Metaphysik des deutschen Idealismus. Vol. GA 49. Edited by Günter Seubold. Frankfurt am Main: Klostermann.

- 1993. Hegel: Die Negativität. Vol. GA 68. Edited by Ingrid Schüssler. Frankfurt am Main: Klostermann.

- 1994. Holzwege. Vol. GA 5. Edited by Friedrich-Wilhelm von Herrmann. Frankfurt am Main: Klostermann.

- 1997. Besinnung. Vol. GA 66. Edited by Friedrich-Wilhelm von Herrmann. Frankfurt am Main: Klostermann. 
- 1998. Die Geschichte des Seyns. Vol. GA 69. Edited by Peter Trawny. Frankfurt am Main: Klostermann (from 1938-40).

- 1999. Metaphysik und Nihilismus. Vol. GA 67. Edited by Hans-Joachim Friedrich. Frankfurt am Main: Klostermann (Die Überwindung der Metaphysik, 1938-9; Das Wesen des Nihilismus, 1946-8).

- 2004. Nietzsche Seminare 1937 und 1944. Vol. GA 87. Edited by Peter von Ructeschell. Frankfurt am Main: Klostermann

- 2005. Phänomenologische Interpretationen ausgewählter Abhandlungen des Aristoteles zur Ontologie und Logik. Vol. GA 62. Edited by Günther Neumann. Frankfurt am Main: Klostermann.

- 2006. Vorträge und Aufsätze. Vol. GA 11. Edited by Friedrich-Wilhelm von Herrmann. Frankfurt am Main: Klostermann.

- 2008. Die metaphysischen Grundstellungen des abendländischen Denkens. Vol. GA 88. Edited by Alfred Denker. Frankfurt am Main: Klostermann

- 2009a. Das Ereignis. Vol. GA 71. Edited by Friedrich-Wilhelm von Herrmann. Frankfurt am Main: Klostermann (dating from 1941-2).

- 2009b. Leitgedanken zur Entstehung der Metaphysik, der neuzeitlichen Wissenschaft und der modernen Technik. Vol. GA 76. Edited by Claudius Strube. Frankfurt am Main: Klostermann

- 2010. Zum Wesen der Sprache und Zur Frage der Kunst. Vol. GA 74. Edited by Thomas Regehly. Frankfurt am Main: Klostermann

- 2011. Seminare: Hegel - Schelling. Vol. GA 86. Edited by Peter Trawny. Frankfurt am Main: Klostermann

- 2013. Zum Ereignis-Denken. Vol. GA 73. Edited by Peter Trawny. Frankfurt am Main: Klostermann

- 2015. Anmerkungen I-IV (Schwarze Hefte 1942-1948). Vol. GA 97. Edited by Peter Trawny. Frankfurt am Main: Klostermann

Kisiel, Theodore, "Recent Heidegger translations and their German originals: A grassroots archival perspective," Continental Philosophy Review, 38 (2006) 263-87.

Pöggeler, Otto, Neue Wege mit Heidegger, Freiburg/München: Alber, 1992.

Ullrich, Wolfgang, Der Garten des Wildnis: Zu Martin Heidegger's Ereignis-Denken, München: Fink, 1996.

Vaysse, Jean-Marie, "Historialité de histoire de L'Être," Heidegger, M. Caron, ed., Paris: Cerf, 2006.

Ziarek, Krysztof, Language After Heidegger, Bloomington: Indiana University Press, 2013. 